\title{
Nicotinic acetylcholine receptor variants associated with susceptibility to chronic obstructive pulmonary disease: a meta-analysis
}

\author{
Jing Zhang ${ }^{1}$, Hanssa Summah², Ying-gang Zhu and Jie-Ming $\mathrm{Qu}^{2^{*}}$
}

\begin{abstract}
Background: Only $10-15 \%$ of smokers develop chronic obstructive pulmonary disease (COPD) which indicates genetic susceptibility to the disease. Recent studies suggested an association between COPD and polymorphisms in CHRNA coding subunits of nicotinic acetylcholine receptor. Herein, we performed a meta-analysis to clarify the impact of CHRNA variants on COPD.

Methods: We searched Web of Knowledge and Medline from 1990 through June 2011 for COPD gene studies reporting variants on CHRNA. Pooled odds ratios (ORs) were calculated using the major allele or genotype as reference group.

Results: Among seven reported variants in CHRNA, rs1051730 was finally analyzed with sufficient studies. Totally 3460 COPD and 11437 controls from 7 individual studies were pooled-analyzed. A-allele of rs1051730 was associated with an increased risk of COPD regardless of smoking exposure (pooled $\mathrm{OR}=1.26,95 \% \mathrm{Cl} 1.18-1.34, \mathrm{p}<$ $\left.10^{-5}\right)$. At the genotypic level, the ORs gradually increased per A-allele (OR $=1.27$ and 1.50 for $G A$ and $A A$ respectively, $\mathrm{p}<10^{-5}$ ). Besides, AA genotype exhibited an association with reduced FEV1\% predicted (mean difference $3.51 \%, 95 \% \mathrm{Cl} 0.87-6.16 \%, \mathrm{p}=0.009)$ and increased risk of emphysema (OR 1.93, 95\% Cl 1.29-2.90, $\mathrm{p}=$ $0.001)$.
\end{abstract}

Conclusions: Our findings suggest that rs 1051730 in CHRNA is a susceptibility variant for COPD, in terms of both airway obstruction and parenchyma destruction.

Keywords: Chronic Obstructive Pulmonary Disease (COPD), Nicotine acetylcholine receptor (nAChR), CHRNA -; , Single nucleotide polymorphism (SNP)

\section{Background}

Chronic obstructive pulmonary disease (COPD) is one of the leading causes of morbidity and mortality worldwide and results in an economic and social burden which is both substantial and still increasing [1]. It is characterized by chronic inflammation and irreversible airflow obstruction which involves structural changes of the lung [2]. Cigarette smoking is the major risk factor for the development of COPD [1]. The chronic inflammatory process induced by tobacco smoking promotes the structural changes in the small airways and

\footnotetext{
* Correspondence: jmqu64@gmail.com

2Department of Pulmonary Medicine, Huadong Hospital, Shanghai Medical

College, Fudan University, Shanghai 200040, China

Full list of author information is available at the end of the article
}

parenchyma [2]. Although COPD is regarded as a consequence of smoking, however, only 10-15\% of longterm smokers develop symptomatic airflow obstruction $[1,3,4]$. This indicates that the genetic factors might contribute to the individual susceptibility. Family studies, case-control studies and the recent hypothesis-free genome-wide association (GWA) studies all support the role of genetic disposition in the development of COPD [5-7].

Several single nucleotide polymorphisms (SNPs) in the gene cluster CHRNA3-CHRNB4-CHRNA5 on chromosome $15 \mathrm{q} 25$ have been identified to be associated with nicotine dependence [8-14]. These SNPs are rs1051730, rs16969968, rs578776, rs8034191, rs588765, rs12914008, and rs931794. The CHRNA3-CHRNB4-CHRNA5 region

\section{Biomed Central}


encodes the subunits of alpha-nicotinic acetylcholine receptor (nAChR), which are expressed not only in neurons but also in other tissues [15]. These receptors play an important role in the lung. They are expressed on structural cells such as bronchial and alveolar epithelial cells [15-17]; and inflammatory cells such as mast cells, neutrophils, monocytes and lymphocytes [18]. Experiments of lung cancer cell line and murine models suggested that pulmonary $\mathrm{nAChR}$ might serve as a regulator of proliferation and apoptosis to carcinogens $[19,20]$. Moreover, the $\alpha 5$ subunit of the nAChR may be involved in modifying the inflammatory response to smoking [21]. The variants in CHRNA have been reported to be related to functional consequences, such as altered receptor response to nicotine agonist [15] and altered mRNA levels of CHRNA5 in brain and lung tissue [22]. Therefore, these variants might cause biological changes in lung, and contributes to the abnormal responses to smoking stimuli observed in COPD patients. Recent studies, especially results from GWA studies, supported the assumption that this genetic locus is also associated with COPD [6,23-29].

In order to confirm a conclusive relationship between genetic locus and susceptibility to COPD, it is important to determine its impact on the development of COPD and COPD-related phenotypes. Individual studies on the association between nAChR polymorphisms and COPD were of limited sample size and there has been a lack of replication between various studies. From the most recent studies focusing on the association between genetic polymorphisms in 15q25 locus and different subtypes of COPD (airway obstruction and emphysema) $[24,25]$, we summarized the current evidence of variants in CHRNA. We also performed a meta-analysis on published case-control studies aiming to confirm the effect of nAChR variants on susceptibility to COPD.

\section{Methods}

\section{Literature search}

Literature search was carried out using electronic databases Web of Knowledge (1990 to June 2011) via library of Fudan University and Medline (1990 to June 2011) by PubMed search engines, with the databases being last assessed on 10 July 2011. The search histories were as follows: (variant OR variation OR genotype OR allele OR polymorphism OR SNP OR single nucleotide polymorphism OR linkage disequilibrium OR haplotype) AND (nicotinic acetylcholine receptor OR nAChR OR CHRNA OR cholinergic receptor nicotinic alpha OR cholinergic nicotinic receptor OR cholinergic receptor OR nicotinic ACh receptor OR nicotinic receptor OR 15q25 OR 15q24/25 OR 15q24-25 OR rs1051730 OR rs16969968 OR rs578776 OR rs8034191 OR rs588765 OR rs12914008 OR rs931794) AND (chronic bronchitis
OR emphysema OR chronic obstructive pulmonary disease OR COPD). The reference lists of relevant publications were manually searched for additional studies.

Ethical approval was not required for this metaanalysis.

\section{Study eligibility and data extraction}

Studies were included if they reported the genotype count or allele frequency. The included studies should be a case-control design, with at least two comparison groups, i.e. COPD and controls. Population-based studies were included, but studies base on family or sibling pairs were excluded. Self-reported COPD were not acceptable as a reliable diagnosis, and therefore studies using such diagnostic criteria were excluded. In case of studies containing the same data sets as studies that had been published before, only the study with the largest sample size was included. Data published only in abstract form or from web-site materials were excluded due to the fact that these studies had not undergone peer-review and the inclusion of these studies might introduce bias into the meta-analysis. Case reports, review articles, and textbook chapters were also excluded from the analysis. Two authors independently reviewed the abstracts of all the studies generated by the literature search. The variants, which were reported by more than 5 independent studies, were further metaanalyzed. The full text articles of all eligible abstracts were reviewed and data were extracted by the two authors. Any discrepancies were resolved by discussion with a third author to reach a final consensus.

The extracted data included: (1) publication details including year of publication, title, name of the first author, and country in which the study was conducted; (2) type of study design; (3) sample size; (4) age range, gender and ethnicity of the study population; (5) COPD definition; (6) smoking history of the studied subjects; (7) allele frequency; (8) genotype counts; (9) phenotypes (bronchial obstruction and/or emphysema); (10) methods which were used to investigate polymorphisms. The authors of the included studies were contacted for additional information if there was no sufficient data for analysis.

\section{Data analysis}

A methodological meta-analysis was conducted to determine the overall association between the candidate variant in CHRNA and COPD. Data from each case-control study were extracted to construct a two-by-two table in which subjects were classified by diagnostic category (COPD versus control) and different genotype or alleles. The odds ratios (ORs) were estimated using the major allele or genotype as the reference group. All the statistical analysis was performed by Review Manager Software 
5.1.2 (Cochrane Collaboration, Oxford, UK). The Chisquare test was used to evaluate the presence of statistically significant heterogeneity across the studies and the inconsistency index $\left(I^{2}\right)$ was used to quantify the amount of heterogeneity [30]. If there was no heterogeneity between studies, a fixed-effect model was used. Otherwise, a random-effect model was used. The significance of the pooled OR was determined by the $\mathrm{Z}$ test, along with $95 \%$ confidence intervals (CI). The presence of publication bias was tested using funnel plots. A p value $<0.05$ was considered as statistically significance.

\section{Results}

\section{Description of studies}

The initial literature search revealed 29 articles, of which 20 were excluded because their title and abstract were irrelevant to our study question. For all the known variants on 15q25, only rs 1051730 was reported by more than 5 independent studies. In the subsequent literature analysis, eleven potentially eligible studies on rs1051730 were identified from the remaining 7 articles [23-29]. The study by Wang et al [29] was excluded because the approach to define COPD was self-reported emphysema rather than spirometer-based criteria. In the Copenhagen City Heart Study, the diagnosis of COPD was based on the ICD coding in the national Danish Cancer, Patient and Death registry [23]. The diagnosis was regarded as reliable because it was registered after hospitalization or outpatient visits. The study by Siedinski et al [28] was excluded because it was a case-only study. The ICGN study and the Boston Early Onset COPD study were family-based analysis, and were also excluded [26]. Finally a total of 7 individual studies from 5 articles met our inclusion criteria. Figure 1 shows the study selection process. In the study by Young et al [27], there were 2 case groups (COPD and lung cancer) and one control group (healthy volunteers). The authors



Figure 1 Study selection process. COPD, chronic obstructive pulmonary disease. compared COPD group with healthy controls, and with non-COPD subjects including healthy controls and patients in lung cancer group without COPD, respectively. Considering the overlap of the frequencies of acetylcholine nicotinic receptor variants between lung cancer and COPD, the data of comparison between COPD and primary healthy controls was included into the current pooled analysis. Therefore, totally 14897 subjects were included in the current analysis, including 3460 COPD and 11437 controls. Table 1 and 2 summarizes the main characteristics of the 7 included studies. These studies were published between 2008 and 2011.

\section{Association between rs1051730 and COPD}

Data from seven independent studies were analyzed for the OR of A-allele using the G-allele as the reference group [23-27]. As the statistical heterogeneity and inconsistency were not found between studies $(\mathrm{p}=0.40$, $\chi 2=6.25, \mathrm{I}^{2}=4 \%$ ), a fix-effect model was used for the analysis. The A-allele was significantly more common in COPD subjects compared with control subjects. As shown in Figure 2, the pooled OR of A-allele was increased to $1.26\left(95 \%\right.$ CI $\left.1.18-1.34, \mathrm{p}<10^{-5}\right)$. Therefore, the A-allele carriers were more susceptible to having COPD.

According to the comparability of smoking exposure (pack-years) between COPD group and control group, we performed a subgroup analysis. As shown in Table 2, the numbers of pack-years were comparable between COPD group and control group in COPACETIC and LEUVEN cohort. The ORs of both subgroup analyses were similar to the overall estimate (Table 3). Besides, we performed pooled-analysis for 3 included studies in which detailed smoking exposure data were provided, and no associations were observed in terms of smoking amount (pack-years), smoking duration (years) or current smoking status (data not shown).

Six studies reported the genotype counts. There was no heterogeneity between studies (for all the comparisons, $\mathrm{p}>0.05$ ), and analysis was performed under a fixeffect model. At the genotypic level, homozygous AA and heterozygous GA carriers exhibited an increased risk of having COPD compared to homozygous GG carriers (Table 4).

The funnel plot for the OR analysis of the frequencies of A-allele and G-allele between COPD and control (Figure 3) suggests symmetry, indicating no evidence of publication bias.

\section{The rs1051730 A-allele carriers showed a reduced lung function}

COPD is a disease characterized with irreversible airflow obstruction which is confirmed by sprirometry. 
Table 1 Characteristics of studies included in the meta-analysis.

\begin{tabular}{|c|c|c|c|c|c|}
\hline Study and reference & Ethnicity/Country & Age & COPD definition & Smoking history & $\begin{array}{l}\text { Methodology of } \\
\text { genotyping }\end{array}$ \\
\hline $\begin{array}{l}\text { Bergen cohort from Pillai et al } \\
\text { [26] }\end{array}$ & NR/Norway & NR & $\begin{array}{l}\text { post-bronchodilator FEV } 1<80 \% \\
\text { predicted and FEV1/FVC }<0.7\end{array}$ & $\begin{array}{l}\text { a minimum smoking } \\
\text { history of } 2.5 \text { pack-years }\end{array}$ & $\begin{array}{l}\text { Illumina's } \\
\text { HumanHap550 } \\
\text { BeadChip }\end{array}$ \\
\hline $\begin{array}{l}\text { Copenhagen City Heart Study } \\
\text { from Kaur-Knudsen et al [25] }\end{array}$ & NR/Denmark & NR & ICD-8 491-492 ICD-10 J41-J44 & NR & TaqMan method \\
\hline $\begin{array}{l}\text { COPDGene study from Kim et } \\
\text { al [24] }\end{array}$ & $\begin{array}{l}\text { non-Hispanic } \\
\text { white subjects/ } \\
\text { America }\end{array}$ & $45-80$ & $\begin{array}{l}\text { post-bronchodilator FEV1 }<80 \% \\
\text { predicted and FEV1/FVC }<0.7\end{array}$ & $\begin{array}{l}\text { a minimum smoking } \\
\text { history of } 10 \text { pack-years }\end{array}$ & TaqMan method \\
\hline $\begin{array}{l}\text { COPACETIC cohort from } \\
\text { Lambrechts et al [23] }\end{array}$ & $\begin{array}{l}\text { NR/the } \\
\text { Netherlands }\end{array}$ & $50-75$ & $\begin{array}{l}\text { pre-bronchodilator FEV1/ } \\
\text { FVC }<0.7\end{array}$ & $\begin{array}{l}\text { a minimum smoking } \\
\text { history of } 20 \text { pack-years }\end{array}$ & $\begin{array}{l}\text { Illumina's } \\
\text { HumanHap610- } \\
\text { Quad BeadChip }\end{array}$ \\
\hline $\begin{array}{l}\text { LEUVEN cohort from } \\
\text { Lambrechts et al [25] }\end{array}$ & NR/Belgium & $>50$ & $\begin{array}{l}\text { post-bronchodilator FEV1/ } \\
\text { FVC }<0.7\end{array}$ & $\begin{array}{l}\text { a minimum smoking } \\
\text { history of } 15 \text { pack-years }\end{array}$ & $\begin{array}{l}\text { ¿PLEXTM genotyping } \\
\text { assay }\end{array}$ \\
\hline $\begin{array}{l}\text { NETT/NAS cohorts from Pillai } \\
\text { et al [26] }\end{array}$ & $\begin{array}{l}\text { non-Hispanic } \\
\text { white subjects/ } \\
\text { America }\end{array}$ & NR & $\begin{array}{l}\text { FEV1 } \leq 45 \% \text { predicted and } \\
\text { bilateral emphysema on chest } \\
\text { CT }\end{array}$ & $\begin{array}{l}\text { cases: former smokers } \\
\text { controls: a minimum } \\
\text { smoking history of } 10 \\
\text { pack-years }\end{array}$ & $\begin{array}{l}\text { Sequenom iPLEX or } \\
\text { TaqMan method }\end{array}$ \\
\hline $\begin{array}{l}\text { New Zealand study from } \\
\text { Young et al [27] }\end{array}$ & $\begin{array}{l}\text { Caucasian/New } \\
\text { Zealand }\end{array}$ & $\begin{array}{l}\text { Case: }>40 \\
\text { Controls: } 45- \\
80\end{array}$ & $\begin{array}{l}\text { post-bronchodilator FEV } 1<80 \% \\
\text { predicted and FEV1/FVC }<0.7\end{array}$ & $\begin{array}{l}\text { a minimum smoking } \\
\text { history of } 15 \text { pack-years }\end{array}$ & $\begin{array}{l}\text { iPLEXTM genotyping } \\
\text { assay }\end{array}$ \\
\hline
\end{tabular}

Abbreviations: NR, not reported; COPD, chronic obstructive pulmonary disease; FEV1, forced expiratory volume in 1 second; FVC, forced vital capacity

Spirometric results were therefore used to analysis the association between SNP rs1051730 and airway obstruction. Three studies presented forced expiratory volume in 1 second $\left(\mathrm{FEV}_{1}\right)$ values against different genotypes. $\mathrm{FEV}_{1} \%$ predicted values in GA and AA genotype were significantly reduced compared to that in GG genotype, with the mean difference being $3.51 \%$ and $6.86 \%$ respectively (Figure 4).

\section{Association between SNP rs1051730 and emphysema}

Emphysema is a major pathological change in patients with COPD, indicating tissue destruction. As shown in Table 5, carriers of A-allele had a higher susceptibility for emphysema (OR 1.39, 95\%CI 1.16-1.68, p = 0.0005). Similarly, AA and GA genotype both showed an increased risk for emphysema compared to GG genotype. The ORs gradually increased per A-allele (OR 1.37, $\mathrm{p}=0.02$ and OR 1.93, $\mathrm{p}=0.001$ ). Because the definition of emphysema was inconsistent in various studies, the number of subjects included in the pooled-analysis was small, but the associations were still statistically significant.

\section{Discussion}

Genetic findings suggest that COPD is associated with the chromosome $15 \mathrm{q} 25$ region, which includes the CHRNA5-CHRNA3-CHRNB4 cluster of cholinergic nicotinic receptor subunit genes [6,12,15,23-29]. Our study only focused on the available case-control COPD studies for this region, and it is the most comprehensive metaanalysis to date on COPD and nAChR genetic susceptibility. We performed both allele-based and genotypebased comparisons. We also had data from the most recent published GWA studies (Bergen and COPACETI cohort [25,26]). Of 7 reported variants in CHRNA, we identified rs1051730 with an adequate number of studies

Table 2 Smoking amounts of COPDs and controls in the included studies.

\begin{tabular}{lll}
\hline Study and reference & \multicolumn{1}{c}{ Pack-years of smoking } \\
\cline { 2 - 3 } & Controls (N) & COPDs (N) \\
\hline Bergen cohort from Pillai et al [26] & $19 \pm 13^{*}(810)$ & NR \\
Copenhagen City Heart Study from Kaur-Knudsen et al [25] & NR & $37 \pm 19^{*}(507)$ \\
COPDGene study from Kim et al [24] & $52 \pm 29^{*}(335)$ & $38.7(29.7-49.5)(161)$ \\
COPACETIC cohort from Lambrechts et al [23] & $38.0(28.0-46.2)(295)$ & $40.0(30.0-57.0)(475)$ \\
LEUVEN cohort from Lambrechts et al [25] & $42.3(30.0-50.5)(184)$ & $66 \pm 30^{*}(389)$ \\
NETT/NAS cohorts from Pillai et al [26] & $40 \pm 28^{*}(472)$ & $47 \pm 20^{*}(458)$ \\
New Zealand study from Young et al [27] & $40 \pm 19^{*}(488)$ & .
\end{tabular}

Abbreviations: Data were presented as median (25th - 75th percentiles) for COPACETIC and LEUVEN cohorts, and as mean \pm SD for other studies. NR, not reported; COPD, chronic obstructive pulmonary disease, defined by spirometric results; ${ }^{*} \mathrm{p}<0.05$ 


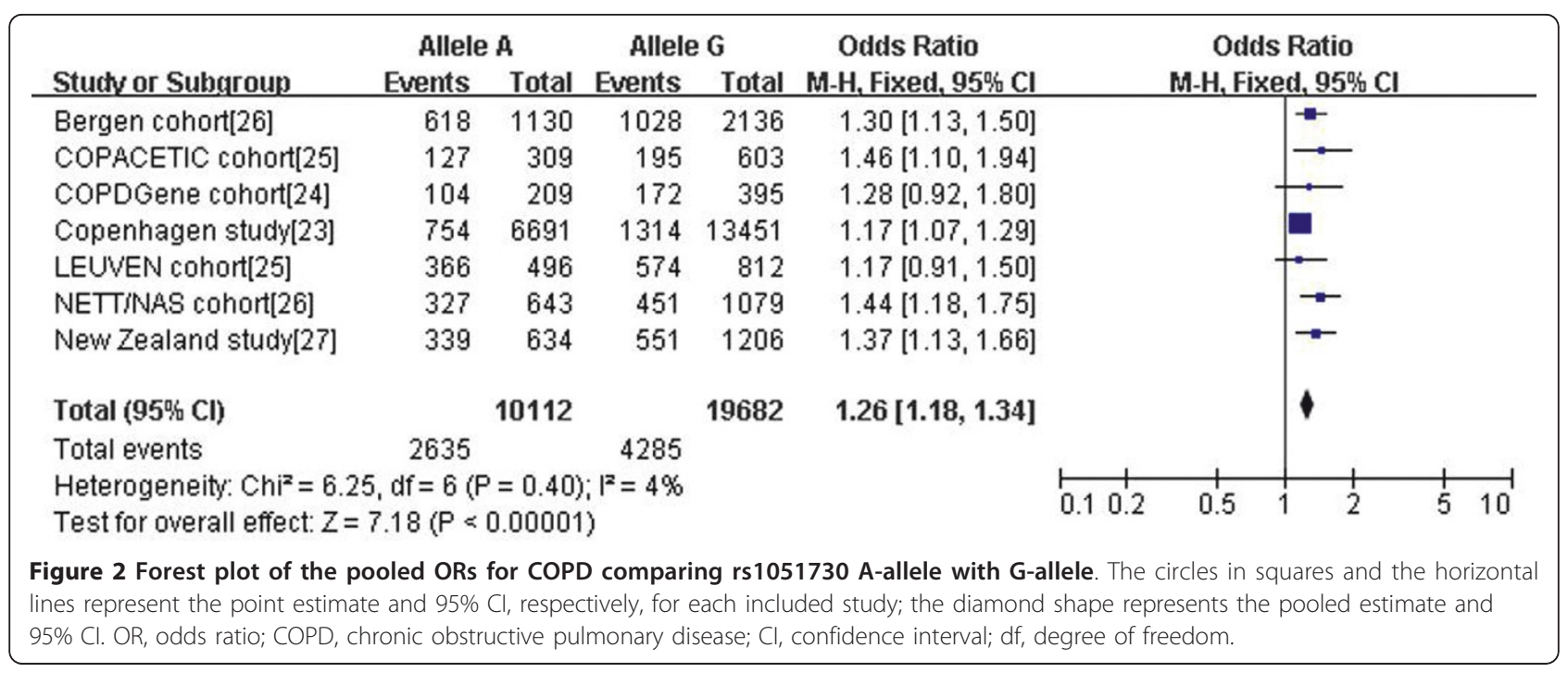

for quantitative pooled-analysis. As shown, A-allele of rs1051730 was significantly associated with a risk of having COPD (OR 1.26, 95\%CI 1.18-1.34, $\mathrm{p}<10^{-5}$ ). In addition, AA genotype, compared to GG genotype, showed statistically significant evidence of association with lower $\mathrm{FEV}_{1} \%$ predicted (mean difference $3.51 \%$, 95\%CI $0.87-6.16 \%, \mathrm{p}=0.009)$ and higher incidence of emphysema (OR 1.93, 95\%CI 1.29-2.90, p = 0.001).

There was limited data about the association between the susceptibility to COPD and other variants in CHRNA. In the COPD GWA study, rs16969968 (which is in strong linkage disequilibrium with rs1051730) showed a weaker association than rs1051730 [26]. In the same GWA study, rs8034191 was related to a higher risk of having COPD. An association between rs8034191 and FEV1 in emphysema was observed in individual studies $[24,26]$. In a recently published meta-analysis with the primary objective to identify the variants affecting smoking quantity in chromosome 15 q25, 3 data sets with COPD trait were used to analysis the relationship between COPD and rs16969968, rs588765, and rs578776, but only rs16969968 showed a suggestive association [12].

The overlap of $\mathrm{nAChR}$ polymorphisms for nicotine dependence and COPD has led to the debate whether polymorphisms in CHRNA have a direct effect on COPD or merely mediate smoking habits $[8,15,27]$.
Saccone et al [12] reported a weak association between rs16969968 and COPD (OR 1.12, 95\%CI 1.01-1.23, p = 0.01 ) after adjusting for cigarettes-per-day, and the estimate was lower than that for cigarettes-per-day. However, the analysis of Saccone et al [12] included selfreported COPD and chronic bronchitis, and this might weaken the association between SNPs and COPD. Results of the current study indicated a stronger association between SNP rs1051730 and spirometer-confirmed COPD, and SNP rs1051730 directly impacts the development of COPD. ORs of SNP rs1051730 for COPD were increased whether the smoking amount was comparable between COPD and control group or not, although the statistical power was stronger when the smoking exposure amount was larger in COPD group than control group (Table 3 ).

The acetylcholine receptors are expressed throughout the lung and mediate the direct effects of nicotine [31]. Besides regulating cholinergic activities in the airways, recent studies demonstrated that they also played a role in cellular proliferation and inflammatory response in the lung $[18,32]$. Therefore the nAChRs could not only be correlated to smoking traits such as cigarettes-perday and smoking addition, but also could be related to other biological effects. Polymorphism of rs1051730 in 15 q25 locus represents a synonymous $G$ to A nucleotide exchange in the CHRNA3 gene. The genetic variant was

Table 3 Association between rs1051730 A-allele and COPD

\begin{tabular}{|c|c|c|c|c|c|c|c|c|}
\hline \multirow[t]{2}{*}{ Smoking amount } & \multicolumn{2}{|c|}{ Number of subjects } & \multicolumn{3}{|c|}{ A-allele vs G-allele effect } & \multicolumn{3}{|c|}{ Heterogeneity } \\
\hline & Control & COPD & OR $(95 \% \mathrm{Cl})$ & Z & $\mathrm{p}$ & $\mathrm{Chi}^{2}$ & $p$ & $I^{2}(\%)$ \\
\hline comparable & 479 & 636 & $1.29(1.07-1.55)$ & 2.62 & 0.009 & 1.34 & 0.25 & 25 \\
\hline incomparable & 2105 & 2177 & $1.35(1.22-1.48)$ & 6.12 & $<10^{-5}$ & 0.77 & 0.86 & 0 \\
\hline
\end{tabular}

Subgroup analysis was performed according to the comparability of smoking amount between COPD and control group of included studies. Abbreviations: COPD, chronic obstructive pulmonary disease; $\mathrm{Cl}$, confidence interval. 
Table 4 Association between rs1051730 genotypes and COPD

\begin{tabular}{ccccccccc}
\hline Genotype & \multicolumn{2}{c}{ Number of subjects } & \multicolumn{2}{c}{ Overall effect } & \multicolumn{3}{c}{ Heterogeneity } \\
\cline { 2 - 8 } & COPD & Total & OR $(\mathbf{9 5} \% \mathbf{C l})$ & $\mathbf{Z}$ & $\mathbf{p}$ & Chi $^{\mathbf{2}}$ & $\mathbf{p}$ & $\mathbf{I}^{\mathbf{2}}(\%)$ \\
\hline GA/GG & $1432 / 1201$ & $6227 / 6188$ & $1.27(1.15-1.40)$ & 4.81 & $<10^{-5}$ & 7.71 & 0.17 & 35 \\
AA/GG & $438 / 1201$ & $1621 / 6188$ & $1.50(1.30-1.73)$ & 5.51 & $<10^{-5}$ & 2.02 & 0.85 & 0 \\
\hline
\end{tabular}

Abbreviations: COPD, chronic obstructive pulmonary disease; $\mathrm{Cl}$, confidence interval.

correlated to the mRNA expression of nAChRs subunits [11]. At the same time, SNP rs1051730 is in linkage disequilibrium with rs16969968, which changes an amino acid (D398N) in alpha5 nicotinic receptor subunits and alters receptor function [15]. These two genetic variants in CHRNA3/5 gene cluster might work together and alter the function of nicotinic receptor in lung tissue and further increase the risk for COPD. Our findings showed that SNP rs1051730 was associated with a reduced $\mathrm{FEV}_{1}$ (Figure 4), and this might be explained by the increase in airway contraction and mucus secretion due to the altered receptor function. An association was also observed with the presence of emphysema (Table 5). In another study, rs1051730 was reported to be associated with emphysema severity in ex-smokers [24]. The data was not included into the current pooled-analysis, because the emphysema severity was expressed in quantitive CT values and the genotype counting was not available. It is plausible that the alteration in peripheral nicotinic receptors might have an impact on tobacco induced tissue destruction. To confirm the direct effect of rs1051730 on COPD, further investigation is needed to measure the mRNA and protein expressions of nAChRs subunits in COPD lungs, as well as the impact of SNP rs1051730 on the functional alterations and its role in the development of COPD and in different subtypes of COPD.

COPD is a multi-factorial disease, and therefore, a variety of genes in the biological pathway of COPD

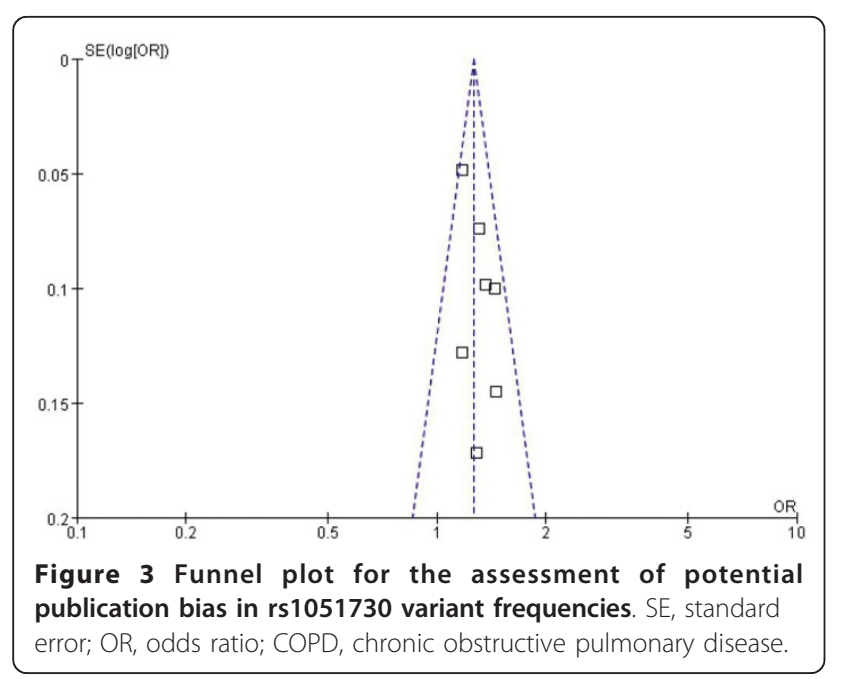

might act together in the development and progression of the disease, and single polymorphism might have interactions with other genetic factors. Apart from SERPINA1 gene encoding the alpha-1 antitrypsin protein $[33,34]$, a series of genetic factors other than nAChR variants have been identified to influence susceptibility to COPD in 6 previous meta-analysis [5,7,35-38]. These polymorphisms were the Tyr113His and His139Arg in EPHX1, IL1RN variable number tandem repeat (VNTR) polymorphism, the GSTM1 null variant, Ile105Val (rs1695) in GSTP1, rs2241712/rs1982073/rs6957/ rs1800470 in TGFB1, 308GA (rs1800629) in TNF and rs1799896 in SOD3. Furthermore, another gene IREB2 was also identified as a potential gene for COPD susceptibility $[39,40]$. IREB2 and CHRNA are both on chromosome $15 \mathrm{q} 25$. It was found that IREB2 protein and mRNA were increased in lung-tissue samples from COPD subjects in comparison to controls. However, further investigations are essentially required in order to understand more about the interaction between rs1051730 and other genes (such as IREB2) for the pathogenesis of COPD in the future.

Our study has the following limitations. First, our study did not consider gene-by-smoking interactions. In all included studies except the Copenhagen City Heart Study, inclusion criteria on smoking history was similar in case and control group (Table 1); however, the smoking amount were comparable only in COPACETIC cohort and LEUVEN cohort (Table 2). Given the importance of smoking in the development of COPD and the known association between nAChR variants and smoking behavior[11,12,15], future studies with equivalent smoking exposure in case and control subjects are required to address this limitation. Second, we only analyzed part of data of COPACETIC GWA study because the full set of results was not available. Third, the imaging protocols in the detection of emphysema are different in various studies. The number of studies for emphysema is therefore insufficient, because the heterogeneity of the calculating methods for emphysema severity. Fourth, all the subjects in the current metaanalysis are European-descendants. Future studies in Asian and African populations would help to determine the ethnic differences of the relationship between rs1051730 and COPD. Finally, publication bias might have influenced some of our results. Exclusion of case- 


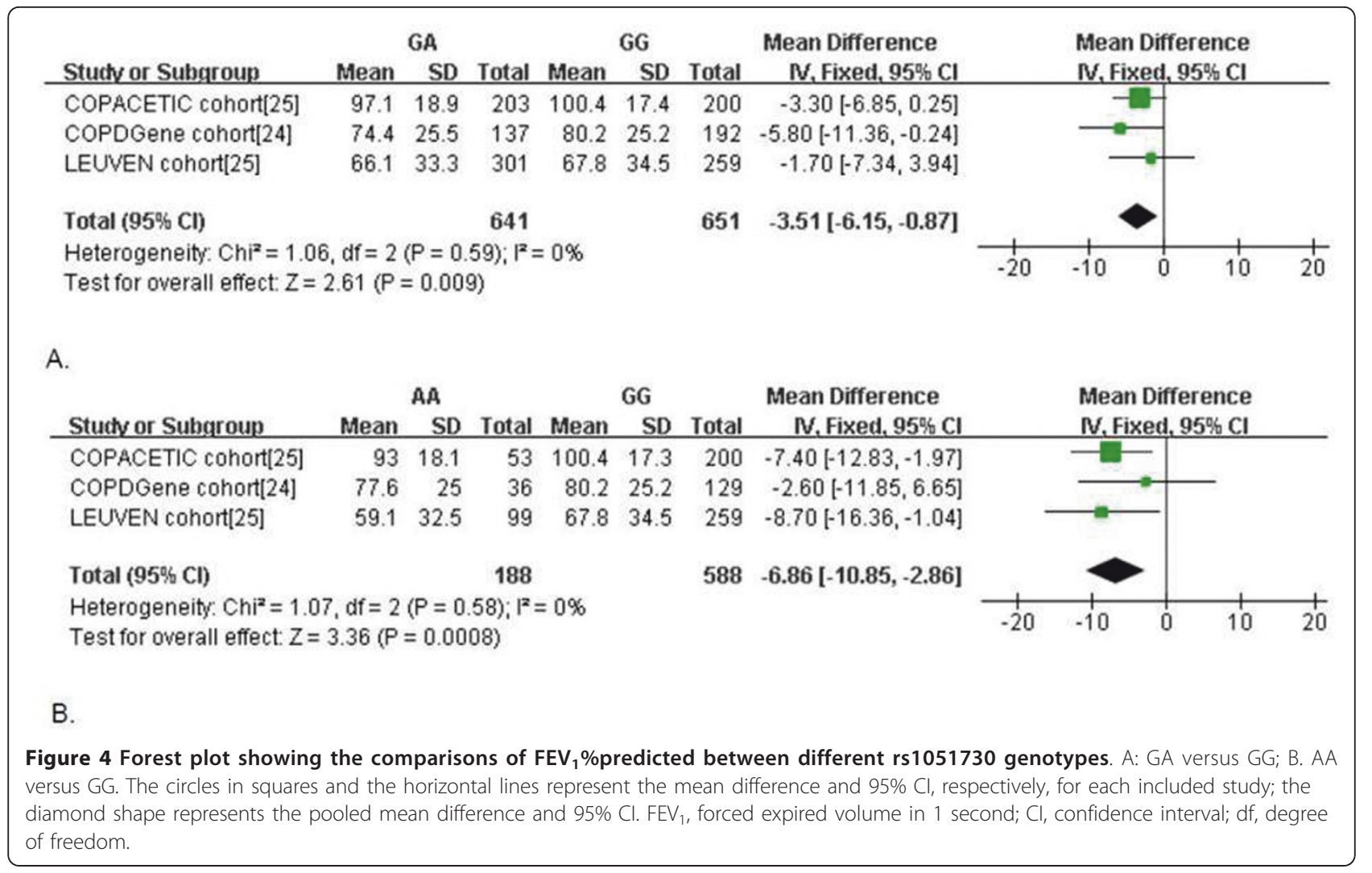

Table 5 Association between rs1051730 genotypes and emphysema

\begin{tabular}{ccccccccc}
\hline \multirow{2}{*}{ Genotype } & \multicolumn{2}{c}{ Number of subjects } & \multicolumn{2}{c}{ Overall effect } & \multicolumn{3}{c}{ Heterogeneity } \\
\cline { 2 - 8 } & COPD & Total & OR (95\%Cl) & Z & $\mathbf{p}$ & Chi $^{\mathbf{2}}$ & $\mathbf{p}$ & $\mathbf{I}^{\mathbf{2}}$ (\%) \\
\hline A-allele/G-allele & $379 / 557$ & $728 / 1288$ & $1.39(1.16-1.68)$ & 3.48 & 0.0005 & 0.01 & 0.94 & 0 \\
GA/GG & $219 / 169$ & $452 / 418$ & $1.37(1.04-1.80)$ & 2.25 & 0.02 & 1.91 & 0.17 & 48 \\
AA/GG & $80 / 169$ & $138 / 418$ & $1.93(1.29-2.90)$ & 3.18 & 0.001 & 0.28 & 0.60 & 0 \\
\hline
\end{tabular}

Abbreviations: $\mathrm{Cl}$, confidence interval.

reports, letters to editors and conference abstracts might have contributed to publication bias. Usually, studies with positive results have a greater chance to be published and studies with inconsistent results of association are usually not published, thus these can potentially increase publication bias in our analysis.

In summary, quantitative meta-analysis identified rs1051730 in CHRNA as a susceptibility variant for the development of COPD, in terms of both airway obstruction and parenchyma destruction. A-allele carriers have a higher risk for COPD, and have a lower $\mathrm{FEV}_{1}$ \%predicted and higher incidence of emphysema. However, many questions are still to be answered before establishing $\mathrm{nAChRs}$ as an interventional target for COPD. Epidemiologic analysis in different ethnic populations, the mediating effect of smoking exposure, and functional studies should be prioritized for further research.

\section{Acknowledgements}

This work was financially supported by Shanghai Young Talents Project of Public Health (No. 08GWQ025), Shanghai Leading Talent Projects (No. 036, 2010) and Shanghai Leading Academic Discipline Project (No. B115). Authors would like to thank Dr. Lian Wu from University of Auckland, New Zealand for English-editing.

\section{Author details}

${ }^{1}$ Department of Pulmonary Medicine, Zhongshan Hospital, Shanghai Medical College, Fudan University, Shanghai 200032, China. ${ }^{2}$ Department of Pulmonary Medicine, Huadong Hospital, Shanghai Medical College, Fudan University, Shanghai 200040, China.

\section{Authors' contributions}

JZ participated in the design of the study, carried out the database search, performed article revaluation and data retraction, and drafted the manuscript. HS carried out article revaluation and the data retraction. YGZ performed the statistical analysis. JMQ conceived of the study, participated in the design and coordination of the study and. All authors read and approved the final manuscript.

Competing interests

The authors declare that they have no competing interests. 
Received: 4 September 2011 Accepted: 17 December 2011

Published: 17 December 2011

\section{References}

1. Global Initiative for Chronic Obstructive Lung Disease: Workshop report: global strategy for the diagnosis, management and prevention of chronic obstructive pulmonary disease [internet] (updated 2009)., Available from: http://www.goldcopd.org/.

2. Hogg JC, Timens W: The pathology of chronic obstructive pulmonary disease. Annu Rev Pathol 2009, 4:435-459.

3. Fletcher C, Peto R: The natural history of chronic airflow obstruction. $\mathrm{Br}$ Med J 1977, 1:1645-1648.

4. Mannino DM, Homa DM, Akinbami LJ, Moorman JE, Gwynn C, Redd SC: Surveillance for asthma-United States, 1980-1999. MMWR Surveill Summ 2002, 51:1-13.

5. Smolonska J, Wijmenga C, Postma DS, Boezen HM: Meta-analyses on Suspected Chronic Obstructive Pulmonary Disease Genes: A Summary of 20 Years' Research. Am J Respir Crit Care Med 2009, 180:618-631.

6. Nakamura H: Genetics of COPD. Allergol Int 2011.

7. Castaldi PJ, Cho MH, Cohn M, Langerman F, Moran S, Tarragona N, Moukhachen H, Venugopal R, Hasimja D, Kao E, Wallace B, Hersh CP, Bagade S, Bertram L, Silverman EK, Trikalinos TA: The COPD genetic association compendium: a comprehensive online database of COPD genetic associations. Human Molecular Genetics 2010, 19:526-534.

8. Baker TB, Weiss RB, Bolt D, von Niederhausern A, Fiore MC, Dunn DM, Piper ME, Matsunami N, Smith SS, Coon H, McMahon WM, Scholand MB, Singh N, Hoidal JR, Kim SY, Leppert MF, Cannon DS: Human neuronal acetylcholine receptor A5-A3-B4 haplotypes are associated with multiple nicotine dependence phenotypes. Nicotine Tob Res 2009, 11:785-796.

9. Falvella FS, Galvan A, Colombo F, Frullanti E, Pastorino U, Dragani TA: Promoter polymorphisms and transcript levels of nicotinic receptor CHRNA5. J Natl Cancer Inst 2010, 102:1366-1370.

10. Saccone NL, Schwantes-An TH, Wang JC, Grucza RA, Breslau N, Hatsukami D, Johnson EO, Rice JP, Goate AM, Bierut LJ: Multiple cholinergic nicotinic receptor genes affect nicotine dependence risk in African and European Americans. Genes Brain Behav 2010, 9:741-750.

11. Bierut $L$ : Convergence of genetic findings for nicotine dependence and smoking related diseases with chromosome 15q24-25. Trends Pharmacol Sci 2010, 31:46-51.

12. Saccone NL, Culverhouse RC, Schwantes-An TH, Cannon DS, Chen $X$, Cichon S, Giegling I, Han S, Han Y, Keskitalo-Vuokko K, Kong X, Landi MT, Ma JZ, Short SE, Stephens SH, Stevens VL, Sun L, Wang Y, Wenzlaff AS, Aggen SH, Breslau N, Broderick P, Chatterjee N, Chen J, Heath AC, Heliovaara M, Hoft NR, Hunter DJ, Jensen MK, Martin NG, et al: Multiple independent loci at chromosome 15q25.1 affect smoking quantity: a meta-analysis and comparison with lung cancer and COPD. PLOS Genet 2010, 6:e1001053.

13. Schwartz AG, Cote ML, Wenzlaff AS, Land S, Amos Cl: Racial differences in the association between SNPs on 15q25.1, smoking behavior, and risk of non-small cell lung cancer. J Thorac Oncol 2009, 4:1195-1201.

14. Stevens VL, Bierut LJ, Talbot JT, Wang JC, Sun J, Hinrichs AL, Thun MJ, Goate A, Calle EE: Nicotinic receptor gene variants influence susceptibility to heavy smoking. Cancer Epidemiol Biomarkers Prev 2008, 17:3517-3525.

15. Bierut $L J$ : Nicotine dependence and genetic variation in the nicotinic receptors. Drug Alcohol Depend 2009, 104(Suppl 1):64-69.

16. Wang Y, Pereira EF, Maus AD, Ostlie NS, Navaneetham D, Lei S, Albuquerque EX, Conti-Fine BM: Human bronchial epithelial and endothelial cells express alpha7 nicotinic acetylcholine receptors. $\mathrm{Mo}$ Pharmacol 2001, 60:1201-1209.

17. Minna JD: Nicotine exposure and bronchial epithelial cell nicotinic acetylcholine receptor expression in the pathogenesis of lung cancer. $J$ Clin Invest 2003, 111:31-33.

18. Carlisle DL, Hopkins TM, Gaither-Davis A, Silhanek MJ, Luketich JD, Christie NA, Siegfried JM: Nicotine signals through muscle-type and neuronal nicotinic acetylcholine receptors in both human bronchial epithelial cells and airway fibroblasts. Respir Res 2004, 5:27.

19. Schuller HM: Is cancer triggered by altered signalling of nicotinic acetylcholine receptors? Nat Rev Cancer 2009, 9:195-205

20. Paleari L, Negri E, Catassi A, Cilli M, Servent D, D'Angelillo R, Cesario A Russo P, Fini M: Inhibition of nonneuronal alpha7-nicotinic receptor for lung cancer treatment. Am J Respir Crit Care Med 2009, 179:1141-1150.
21. Gwilt CR, Donnelly LE, Rogers DF: The non-neuronal cholinergic system in the airways: an unappreciated regulatory role in pulmonary inflammation? Pharmacol Ther 2007, 115:208-222.

22. Wang JC, Cruchaga C, Saccone NL, Bertelsen S, Liu P, Budde JP, Duan W, Fox L, Grucza RA, Kern J, Mayo K, Reyes O, Rice J, Saccone SF, Spiegel N, Steinbach JH, Stitzel JA, Anderson MW, You M, Stevens VL, Bierut LJ, Goate AM: Risk for nicotine dependence and lung cancer is conferred by mRNA expression levels and amino acid change in CHRNA5. Hum Mol Genet 2009, 18:3125-3135.

23. Kaur-Knudsen D, Bojesen SE, Tybjaerg-Hansen A, Nordestgaard BG: Nicotinic Acetylcholine Receptor Polymorphism, Smoking Behavior, and Tobacco-Related Cancer and Lung and Cardiovascular Diseases: A Cohort Study. J Clin Oncol 2011, 29:2875-2882.

24. Kim DK, Hersh CP, Washko GR, Hokanson JE, Lynch DA, Newell JD, Murphy JR, Crapo JD, Silverman EK: Epidemiology, radiology, and genetics of nicotine dependence in COPD. Respir Res 2011, 12:9.

25. Lambrechts D, Buysschaert I, Zanen P, Coolen J, Lays N, Cuppens H, Groen HJM, Dewever W, van Klaveren RJ, Verschakelen J, Wijmenga C Postma DS, Decramer M, Janssens W: The 15q24/25 Susceptibility Variant for Lung Cancer and Chronic Obstructive Pulmonary Disease Is Associated with Emphysema. Am J Respir Crit Care Med 2010, 181:486-493.

26. Pillai SG, Ge D, Zhu G, Kong X, Shianna KV, Need AC, Feng S, Hersh CP, Bakke P, Gulsvik A, Ruppert A, Lodrup Carlsen KC, Roses A, Anderson W, Rennard SI, Lomas DA, Silverman EK, Goldstein DB: A genome-wide association study in chronic obstructive pulmonary disease (COPD): identification of two major susceptibility loci. PLoS Genet 2009, 5: e1000421.

27. Young RP, Hopkins RJ, Hay BA, Epton MJ, Black PN, Gamble GD: Lung cancer gene associated with COPD: triple whammy or possible confounding effect? Eur Respir J 2008, 32:1158-1164.

28. Siedlinski M, Cho MH, Bakke P, Gulsvik A, Lomas DA, Anderson W, Kong X, Rennard SI, Beaty TH, Hokanson JE, Crapo JD, Silverman EK: Genome-wide association study of smoking behaviours in patients with COPD. Thorax 2011, 66:894-902.

29. Wang J, Spitz MR, Amos Cl, Wilkinson AV, Wu X, Shete S: Mediating effects of smoking and chronic obstructive pulmonary disease on the relation between the CHRNA5-A3 genetic locus and lung cancer risk. Cancer 2010, 116:3458-3462.

30. Higgins JP, Thompson SG: Quantifying heterogeneity in a meta-analysis. Stat Med 2002, 21:1539-1558

31. Wessler I, Kirkpatrick CJ, Racke K: Non-neuronal acetylcholine, a locally acting molecule, widely distributed in biological systems: expression and function in humans. Pharmacol Ther 1998, 77:59-79.

32. Kanazawa $\mathrm{H}$ : Anticholinergic agents in asthma: chronic bronchodilator therapy, relief of acute severe asthma, reduction of chronic viral inflammation and prevention of airway remodeling. Curr Opin Pulm Med 2006, 12:60-67.

33. Ganrot PO, Laurell CB, Eriksson S: Obstructive lung disease and trypsin inhibitors in alpha-1-antitrypsin deficiency. Scand J Clin Lab Invest 1967, 19:205-208.

34. Stoller JK, Aboussouan LS: Alpha1-antitrypsin deficiency. Lancet 2005 365:2225-2236.

35. Hu G, Yao W, Zhou Y, Hu J, Shi Z, Li B, Ran P: Meta- and pooled analyses of the effect of glutathione S-transferase M1 and T1 deficiency on chronic obstructive pulmonary disease. Int J Tuberc Lung Dis 2008, 12:1474-1481.

36. Brogger J, Steen VM, Eiken HG, Gulsvik A, Bakke P: Genetic association between COPD and polymorphisms in TNF, ADRB2 and EPHX1. Eur Respir J 2006, 27:682-688

37. Gingo MR, Silveira LJ, Miller YE, Friedlander AL, Cosgrove GP, Chan ED, Maier LA, Bowler RP: Tumour necrosis factor gene polymorphisms are associated with COPD. Eur Respir J 2008, 31:1005-1012.

38. Hu G, Shi Z, Hu J, Zou G, Peng G, Ran P: Association between polymorphisms of microsomal epoxide hydrolase and COPD: results from meta-analyses. Respirology 2008, 13:837-850.

39. DeMeo DL, Mariani T, Bhattacharya S, Srisuma S, Lange C, Litonjua A, Bueno R, Pillai SG, Lomas DA, Sparrow D, Shapiro SD, Criner GJ, Kim HP, Chen Z, Choi AMK, Reilly J, Silverman EK: Integration of genomic and genetic approaches implicates IREB2 as a COPD susceptibility gene. Am J Hum Genet 2009, 85:493-502. 
40. Chappell SL, Daly L, Lotya J, Alsaegh A, Guetta-Baranes T, Roca J, Rabinovich R, Morgan K, Millar AB, Donnelly SC, Keatings V, MacNee W, Stolk J, Hiemstra PS, Miniati M, Monti S, O'Connor CM, Kalsheker N: The role of IREB2 and transforming growth factor beta-1 genetic variants in COPD: a replication case-control study. BMC Med Genet 2011, 12:24.

doi:10.1186/1465-9921-12-158

Cite this article as: Zhang et al:: Nicotinic acetylcholine receptor variants associated with susceptibility to chronic obstructive pulmonary disease: a meta-analysis. Respiratory Research 2011 12:158.

Submit your next manuscript to BioMed Central and take full advantage of:

- Convenient online submission

- Thorough peer review

- No space constraints or color figure charges

- Immediate publication on acceptance

- Inclusion in PubMed, CAS, Scopus and Google Scholar

- Research which is freely available for redistribution

Submit your manuscript at www.biomedcentral.com/submit 